The History of Sexually Transmitted Diseases. No 11 in a series edited by Milton Lewis and Michael Waugh.

\title{
The history of venereal disease and yaws (parangi) in Sri Lanka (Ceylon)
}

\author{
P Ariyaratne De Silva, Michael G Gomez
}

Sri Lanka, formerly called Ceylon, is a small island in the Indian Ocean, located about 500 miles north of the Equator, very close to the southern tip of India. It is about the size of Ireland and has a tropical climate. It is the home of a multiethnic community of about 17.2 million people, comprised of Singhalese (about 74\%), Tamils (about 18\%), Muslims (about 7\%), and Burghers, (the descendants of Dutch colonists and Eurasians) and others, (less than $1 \%) .^{1}$ India had the greatest influence on the culture, religious beliefs and medical practices of Ceylon, until colonization by the Portuguese (1505-1658), the Dutch (1658-1796) and the British (1796-1948). Over the years Sri Lanka has made substantial progress in the delivery of health care and enjoys one of the best health statuses in South Asia. Primary health care is adequate, with low birth and death rates and high immunisation uptake. Sri Lanka has had a reasonably good infrastructure in the past, for the control of sexually transmitted diseases. However this has been subjected to intermittent assault due to political decisions, civil disturbances, funding cuts, and changing availability of trained medical personnel. In this context the contribution made by the WHO appears to be constructive.

\section{Early history}

The earliest records indicate that India and Ceylon led the way in the region in establishing hospitals and medical care. Certainly in Ceylon the practice of medicine was consistent with the holding of the highest status in the land, and many kings and noblemen were associated with the art of healing. King Buddadasa, who reigned at Anuradhapura in the 5th century A.D., was himself an eminent physician and according to Mahavansa (Great Chronicle) composed an ancient Aurvedic book the Saratha sangrahava. Venereal disease (and a disease like syphilis in particular) is mentioned in this book. ${ }^{2}$ The more recent history of venereal disease in Ceylon has been documented in Yogaratnacara, a book containing the native system of medicine composed around 1548 A.D. ${ }^{3}$ The Portuguese Period Captain Joao Ribeiro's book, presented to the King of Portugal in 1685 and entitled History of Ceylon, states that "syphilis, they (people of Ceylon) call, Parangi leda, which means Portuguese disease and with reason for it was we who introduced it among them". In the Singhalese language, Parangi refers to foreigners. As the Portuguese were the first
Europeans whom local people encountered, they were referred to as the "parangies". Some believe that "parangi leda", later described as Parangi was in fact yaws. ${ }^{4}$ It is highly probable that African slaves who accompanied the Portuguese brought yaws into Ceylon. However, it is likely that syphilis was also prevalent among the Portuguese at that time. Another book on native medicine, Bhesajju Nidane, mentions eight varieties of Parangi. ${ }^{5}$

\section{The British colonial government's concern and response}

No attempts had been made for well over three centuries to control the spread of Parangi and by this time the disease had caused depopulation of rural villages, mainly in the dry zone. The attention of the government was drawn to the problem in 1866 , as a result of remarks made in the Legislative Council Committee on Irrigation Works and Rice Cultivation. ${ }^{6}$ Senior civil servants and administrators were very concerned with the problem and their continued interest assisted the medical authorities in development of controls.

Dr James Loos, a colonial surgeon, was appointed in 1868 to study the Parangi disease and he observed that its eradication depended upon the advancement of living standards and the adoption of improved habits of life. His recommendations included: (1) the improvement of water supply, especially the repair of ancient tanks (reservoirs), (2) the establishment of more hospitals and dispensaries, (3) the establishment of a medical school in Colombo for training of a class of efficient medical practitioners.

In 1872, Dr Gavin Milroy, reading Loos' report, found similarities between the Parangi disease and yaws, which he had studied in the West Indies. ${ }^{7}$

The first attempt to estimate the incidence of Parangi disease in Ceylon was made in 1879 , in the Parangi census. Data collected by the village Headmen are shown in table 1 .

Hospitals were provided by the government in various parts of the island for the treatment of Parangi patients and parangi wards were opened in existing hospitals. But the disease continued to be prevalent for many years. While people themselves used various remedies, quacks recommended mercury often to the point of salivation. Orthodox medical opinion favoured potassium iodide and strongly condemned the treatment with mercury. 
Table 1 Number of cases of Parangi in 1879, by sex and race in seven Provinces ${ }^{3}$

\begin{tabular}{|c|c|c|c|c|c|c|}
\hline \multirow[b]{2}{*}{ Province } & \multirow{2}{*}{$\begin{array}{l}\text { Total } \\
\text { population }\end{array}$} & \multicolumn{2}{|l|}{ Sex } & \multicolumn{3}{|l|}{ Race } \\
\hline & & Male & Female & Singhalese & Tamil & Moorish \\
\hline $\begin{array}{l}\text { Western } \\
\text { North-Western } \\
\text { Central } \\
\text { North-Central } \\
\text { Northern } \\
\text { Eastern } \\
\text { Southern } \\
\text { Total }\end{array}$ & $\begin{array}{r}360 \\
711 \\
573 \\
294 \\
489 \\
1120 \\
6758 \\
10305\end{array}$ & $\begin{array}{r}255 \\
423 \\
396 \\
167 \\
279 \\
674 \\
4265 \\
6459\end{array}$ & $\begin{array}{r}105 \\
288 \\
177 \\
127 \\
210 \\
446 \\
2493 \\
3846\end{array}$ & $\begin{array}{r}356 \\
670 \\
549 \\
209 \\
28 \\
137 \\
6750 \\
8899\end{array}$ & $\begin{array}{r}4 \\
18 \\
4 \\
29 \\
442 \\
716 \\
0 \\
1213\end{array}$ & $\begin{array}{r}0 \\
23 \\
20 \\
56 \\
19 \\
267 \\
8 \\
393\end{array}$ \\
\hline
\end{tabular}

With patients admitted to hospital, the following steps were taken: (a) warm bath and skin well washed with soap, (b) tepid bath daily, (c) the ulcers were well dressed with carbolic acid ointment, (d) the internal use of iodide of potassium with decoction of sarasaparilla followed by a course of cod liver oil and iodide of iron, (e) nutritious food.

The identification of the causative organism of parangi

Dr Aldo Castellani (1877-1971) who arrived in Ceylon in 1903 was soon asked to investigate the cause of the most common and important disease in the island. Parangi by this time had spread widely. In some districts more than half the population was afflicted and over 50,000 cases were being treated every year in government hospitals and dispensaries. ${ }^{8}$ Dr Castellani described Parangi as " $a$ horrible disease in which the whole body is covered with red fungating excrescences the size of a cherry and with a granular, raspberry-like surface (hence the term framboesia, derived from the French word framboise for raspberry). The eruption disappears after a few months, but the infection remains dormant, and years later enormous ulcers develop and the bones are affected. The disease is not hereditary and a mother whose whole body is covered with horrible sores will give birth to a perfectly healthy and smooth-skinned baby". The causative organism of Parangi was isolated by Dr Castellani from ulcerated lesions and named Spirochaeta pertenuis (pertenue means weak). ${ }^{9}$

During his period of stay in Ceylon (1903-1915), Dr. Castellani held many positions: Professor of Tropical Medicine, Lecturer in Dermatology in the Medical College, Colombo, Director of the Government Bacteriological Institute, Director of the Colombo Clinic for Tropical Diseases, and Physician to the Seamen's ward of the General Hospital, Colombo.

Independently F C Wellman (1905) found Spirochaeta pertenue in yaws. ${ }^{10}$ In 1910 Ehrlich introduced the arsenical compound, Salvarsan, and this was found to be much more effective than iodide for the treatment of Parangi. However, Salvarsan was not regularly available in Ceylon till about 1919 because of the First World War.

\section{The parangi committee}

In 1922 a committee was appointed to inquire into and report on the prevalence of parangi in Ceylon with a view to making adequate provision for coping with the disease. ${ }^{11}$
Dr R L Spittel, an eminent Fellow of the Royal College of Surgeons, and a member of the Parangi Committee wrote: "Framboesia (parangi) is now endemic in Ceylon, flourishes best not in the large towns and highways of civilization where it is practically unknown, but in the remote villages and scattered forest settlements; more from the condition of life than geographical peculiarity. The disease is not in the higher and colder regions of the central mountain massif. It hardly ever attacks the European or for that matter any clean living individual, whatever his race". ${ }^{12} \mathrm{He}$ continued: "To ask the villagers to foregather at central injecting stations is to expect too much of folk constrained to glean a scanty living from day to day. There is but one way to meet the problem and that is by sending out medical men equipped to travel to inject these people in their homes".

The following measures were recommended by the Parangi Committee; (a) that a map showing the infected area in each province be prepared, (b) that compulsory notification through the Headmen and compulsory treatment in the declared areas, under the quarantine and prevention of the Disease Ordinance be instituted, (c) that a senior medical officer and a further four "itinerating" medical officers (I.M.O.), in addition to the three already employed, be provided, (d) that an ample supply of neosalvarsan or similar drugs be provided. This campaign to control parangi was so successful that in 1931 the principal medical officer was able to report that the disease was almost eliminated from most parts of the island.

Various other factors were also responsible for the recession of parangi. These included geographical and natural features of the country. Flat terrain, the absence of serious natural barriers and a widespread road system providing easy access to the most distant parts of the island were important factors.

\section{Social factors}

People started to use soap in place of vegetable lathering products; soap had first been imported in $1850 . .^{13}$ The per capita usage of soap compared favourably with the decline of the endemic disease. Ancient irrigation tanks were repaired and a better water supply provided. In some villages the attitude towards parangi changed and great stigma became attached to the disease. On the subject of parangi control, W.H.O. consultant, $\mathrm{Dr}$ S M Laird commented in 1952: "The history of parangi and its eradication from Ceylon deserves to be written and should provide a fascinating and perhaps a unique chapter of the global story of yaws control". ${ }^{14}$ There is a parallel here in the role of soap in the relationship between the non-venereal form of syphilis (endemic syphilis) and venereal syphilis in the West. Morton has observed, concerning the causes of the change in the relationship, "under the influence of the Renaissance, socioeconomic improvements and the more extensive use of soap, discovered at the end of 14th century, the social contact elements began to die out while the venereal form grew commoner". ${ }^{15}$ 
Venereal diseases and their control

Measures to control venereal diseases in Ceylon were in place well over one hundred years ago and these resembled measures operating in the United Kingdom. Three hospitals were in use, one each in Colombo, Kandy and Galle. They were called Lock hospitals (wards), after similar institutions in the United Kingdom.

Certainly, in Ceylon the inmates of these Lock hospitals did not enter voluntarily. They were exclusively female prostitutes, and were released only on magistrates' orders. The service personnel were treated in the military hospitals and these were for males only. There were no facilities available for the treatment of civilian males.

The contagious disease ordinance

This ordinance was drawn up in 1867 to limit the spread of venereal diseases. It entailed the registration and periodical examination of female prostitutes. Gonorrhoea was the most prevalent venereal disease among them ${ }^{4}$ (table 2).

At this time the diagnosis of most of these conditions was purely clinical and much reliance should not be placed on the accuracy of these figures.

Military hospitals during this time showed a higher prevalence of syphilis (table 3 ).

There had been an increase in the cases treated in both Lock and military hospitals. By 1886, Lock hospitals were treating well over 1000 patients per year and military hospitals, well over 300 patients. The bulk of

Table 2 Cases treated in the Lock wards in 1878

\begin{tabular}{lcccr}
\hline Disease & Colombo & Kandy & Galle & Total \\
\hline Primary syphilis & 43 & 22 & 32 & 97 \\
Secondary syphilis & 2 & 13 & 1 & 16 \\
Gonorrhoea & 111 & 53 & 131 & 295 \\
Leucorrhoea & 31 & 1 & - & 36 \\
Bubo & 5 & - & - & 6 \\
Ulcer & 70 & - & 5 & 70 \\
Labial abscess & 1 & 94 & 170 & 5 \\
Condylomata & - & 263 & & 527 \\
Total & &
\end{tabular}

Table 3 Venereal disease cases treated in the military hospital in $1878^{4}$

\begin{tabular}{llllc}
\hline Disease & Colombo & Kandy & Galle & Total \\
\hline Primary syphilis & 50 & 10 & 11 & 71 \\
Gonorrhoea & 30 & 10 & 7 & 47 \\
Balanitis & - & 20 & 1 & 1 \\
Total & 80 & 19 & 119 \\
\hline
\end{tabular}

Table 4 Cases treated in 1886 and 1889 in Colombo and other hospitals in Ceylon

\begin{tabular}{|c|c|c|c|c|c|c|}
\hline \multirow[b]{2}{*}{ Disease } & \multicolumn{2}{|c|}{$\begin{array}{l}\text { General Hospital } \\
\text { Colombo }\end{array}$} & \multicolumn{2}{|c|}{$\begin{array}{l}\text { Other Hospitals } \\
\text { in Ceylon }\end{array}$} & \multicolumn{2}{|l|}{ Total } \\
\hline & 1886 & 1889 & 1886 & 1889 & 1886 & 1889 \\
\hline Primary syphilis & 334 & 65 & 646 & 619 & 980 & 684 \\
\hline Secondary syphilis & 125 & 59 & 347 & 360 & 472 & 684 \\
\hline Tertiary syphilis & 3 & - & 1 & 2 & 4 & 2 \\
\hline Congenital syphilis & 4 & 2 & - & 7 & 4 & 9 \\
\hline Gonorrhoea & 525 & 32 & 299 & 328 & 824 & 360 \\
\hline Bubo-gonorrhoeal & 24 & 34 & 16 & 34 & 40 & 68 \\
\hline Orchitis (gonorrhoeal) & - & - & 2 & 7 & 2 & 7 \\
\hline Epididymitis (gonorrhoeal) & 5 & - & 8 & 1 & 13 & i \\
\hline Arthritis (gonorrhoeal) & - & 7 & 6 & 7 & 6 & 14 \\
\hline Ophthalmia (gonorrhoeal) & - & - & 1 & - & 1 & - \\
\hline
\end{tabular}

patients were treated in Colombo. The 1886 Administrative report included for the first time the venereal diseases treated in the government hospitals and table 4 gives comparative figures for Colombo and the outstation hospitals.

By 1899 treatment was provided at the Lock hospitals as well as 25 other institutions in various parts of the country. However, the control of venereal diseases was flawed as the diagnosis was clinical and no attempts were made to pursue contact investigation or public education.

\section{The venereal disease commission}

Following recommendations made by $\mathrm{Mr}$ (later Sir) Winston Churchill, the Venereal Disease Commission was set up in 1921. The Commission recommended facilities for treatment be made available to all people, public education be given a high profile and notification be made compulsory.

A clinic was opened in the port of Colombo in 1921 for the treatment of seamen and a clinic was opened as a branch of the Lock hospital in Colombo for the treatment of women and children. Another clinic was established at the outpatient department of the General Hospital, Colombo, for the treatment of civilian males. Neosalvarsan was made available to all government hospitals. Although the treatment was free at these institutions, only the poor and the lower socio-economic groups accepted it, while the rich sought private treatment.

Cases reported in 1922 from the V.D. clinic in Colombo included figures for chancroid for the first time (table 5).

At this stage microscopy and serological tests were available and became an important part of the diagnosis.

On 4 November 1926 Ceylon undertook to observe the provision of the Brussels Agreement of $1924 .{ }^{17}$ In 1939 free laboratory services for the diagnosis of V.D. were provided and a V.D. Control Programme was established under the direction of a specially trained surgeon. Public education about venereal diseases was intensified. V.D. Ordinance No. 27 was introduced in 1938, giving more powers for the control of venereal diseases. Procaine penicillin monostearate (PAM) became available for the treatment of syphilis in 1950 and about the same time personnel (Public Health Inspectors) were trained in contact tracing and follow-up of defaulters. ${ }^{18}$ These spasmodic efforts over 30 years to tackle V.D. in Ceylon lacked direction and continuity, and the temporary gains of each isolated effort were rapidly lost. ${ }^{19}$

The new improvements in the control of venereal diseases arising from more effective

Table 5 Venereal diseases treated in Colombo V.D. clinic in 1922

\begin{tabular}{lr}
\hline Primary syphilis & 109 \\
Secondary syphilis & 369 \\
Tertiary syphilis & 34 \\
Chancroid & 182 \\
Gonorrhoea & 318 \\
Yaws & 92
\end{tabular}


treatment with penicillin and the example of the intensive syphilis programmes implemented by countries like the U.S.A. following the Second World War probably encouraged the Director of Medical and Sanitary Services in Ceylon to give a high priority to the control of venereal diseases. ${ }^{20}$ The Kandyan Peasantry Commission also strongly recommended a strong campaign against venereal diseases. $^{21}$

\section{World Health Organization assistance}

In November 1949, at the request of the Government of Ceylon, Professor George Leiby, W.H.O. consultant, issued a report ${ }^{22}$ making detailed proposals for a comprehensive V.D. Control Programme for the island. Following his recommendations and those of two other W.H.O. consultants (Dr T Guthie and Dr N Janguliwallah), a venereal disease control team under the leadership of $\operatorname{Dr} S M$ Laird came to Ceylon in July 1951. By this time there was a shortage of experienced doctors to run the clinic in Colombo, especially the male section. The chief objectives of this W.H.O. team were: to establish a model V.D. clinic in Colombo to serve as the main clinic for the training of the medical and paramedical staff; to develop a full-time V.D. service with trained staff in the major outstations; to establish the serological testing for syphilis of expectant mothers and thus to control congenital syphilis; to train local staff in serological testing to provide such facilities in the main outstation centres; to develop the diagnostic and treatment facilities for seafarers. ${ }^{22}$ The results achieved by this W.H.O. team were quite remarkable. By March 1952 the model clinic was completed and functioning in Colombo. By April 1952 serological testing of antenatal patients was begun at the major maternity hospital in Colombo and was then extended to six municipal clinics. In June in the same year, the first batch of medical officers was recruited for training and training was completed in August. With the development of the model clinic, the much needed public education campaign was initiated and the national press and the radio assisted in these activities. During 1953 the anti V.D. campaign was extended with the provision of seven clinics with trained staff in major outstation towns. In the 1940 s penicillin replaced the sulphonamides used (from about 1937) for the treatment of gonorrhoea and it was very effective even in very low doses compared with modern treatment. Arsenic and bismuth, which were the treatment for both yaws and syphilis from about 1920, gave way to penicillin in 1950 . However, a complete course was not more than 300,000 units of penicillin aluminium monostearate (P.A.M.) daily for three days!

As the magnitude of the problem of the prevalence of venereal disease was not known, serological testing of five distinct groups was undertaken and high priority was given to the testing of expectant mothers. ${ }^{24}$

The serological survey produced the following conclusions: in 6,067 expectant mothers attending antenatal clinics between 1952 and 1953, serological tests were positive in not fewer than $4 \%$, in 2,288 men in different occupational groups, the average incidence of seropositivity was $4 \%$.

When it was possible to re-examine serologically positive cases, the history and/or clinical findings largely confirmed the serological results.

\section{The Port Venereal Disease Project}

In October 1958 the Port Venereal Disease Clinic, Colombo was opened and patients were seen daily in the afternoon by the staff from the Central V.D. Clinic. The new clinic was open to seafarers and to persons working in close proximity to the port of Colombo. Later similar clinics were opened at the other two ports, Trincomalee and Galle.

The work of the Anti Venereal Disease Campaign (AVDC) had become national by 1953 and this work was carried out so successfully that in 1958, when Dr Laird revisited, he observed that " $A V D$ Campaign has made solid progress and that the initial improvement stimulated by the WHO team during 1951-53 has been extended by the national staff'. ${ }^{25}$

The increased prevalence of venereal diseases The incidence of early syphilis gradually declined and in 1957 it reached a low level: 229 cases in Colombo and 165 cases in the outstation clinics. However, by 1966 there was a threefold increase in the incidence. It is felt that the international industrial exhibition held in Colombo in February-March 1965 was a significant factor in the increased incidence of syphilis experienced in that city. Since the exhibition also travelled to some provincial towns (Kandy, Anuradhapura, Ratnapura, Ragama, Badulle and Horana) it may have contributed to the increase of V.D. in the outstations as well. ${ }^{26}$ It is widely recognised that certain national festivals are important factors in the spread of venereal diseases.

\section{Venereal diseases in the modern period}

There have been considerable fluctuations in the prevalence of the venereal diseases in Sri Lanka in the modern era. Centralised control of all activities under the Anti Venereal Disease Campaign and the dedication of the medical officers in charge and others were prominent features which determined the success of such activities. Even though there has been a rapid increase in male and female prostitution, mainly in the urban areas and in areas where the influence of tourism is apparent during the last 20 years, most Sri Lankans have very conservative attitudes to sex. The pursuit of behaviour styles, which carry a higher risk of venereal disease, are highly stigmatised. This stigmatisation spills over to affect the rest of the family. Hence in a culture where social acceptability is an important factor, there is considerable reluctance to seek medical advice and treatment regarding venereal diseases. This is particularly obvious with regard to government clinics. 
Thus the figures quoted (table 6) are of value only in indicating broad trends in venereal diseases, as a large number of general practitioners treat these diseases and in many cases may not be reporting them. ${ }^{27}$ It is estimated that fewer than one third of patients with sexually transmitted diseases seek treatment in government hospitals and clinics. ${ }^{28}$ When Sri Lanka had reasonably effective anti-venereal activities, the recorded incidence of syphilis was around 30 per 100,000 population in 1976, and this had dropped to about $2 \cdot 8$ per 100,000 in 1988 . The incidence of gonorrhoea has registered a similar fall and was about 13 per 100,000 . A survey among prisoners has shown a seroprevalence for syphilis around $4 \%$ while the tea estate sector had a seroprevalence of around $5 \%$. As antenatal serological testing for syphilis is not performed in most outstations, and some of the blood donors are not tested for serological evidence of syphilis, it is very hard to estimate the actual size of the problem of syphilis in Sri Lanka. However, compared with the early $1950 \mathrm{~s}$, there is evidence that an appreciable reduction in early congenital syphilis and symptomatic syphilis has been achieved.

However, penicillin and other antibiotics have much less influence on the gonococcal infection rates. Chancroid is diagnosed less frequently than early infectious syphilis. Clinical manifestations of chancroid are being localised and respond well to treatment. It does not pose a great problem in Sri Lanka. It is interesting to note that both lymphogranuloma venereum and granuloma inguinale are rare in Sri Lanka, even though both are common in the neighbouring countries.

\section{HIV infection and the government response}

In 1986 the Government of Sri Lanka established the National AIDS Task Force, before the appearance of indigenous AIDS patients. The scope of activity was further widened by forming a National AIDS Committee in 1988. A National Medium Term Plan (MTP) for the Prevention and Control of AIDS and Sexually Transmitted Diseases was prepared in November 1988 by the Anti Venereal Disease Campaign (AVDC) of the Ministry of Health in cooperation with the World Health Organization.

The Medium Term Objectives of the Programme are: monitoring the incidence of infection through surveillance of identified high risk groups; instituting HIV screening of all blood collected and utilised in the public sector; applying strict sterilisation practices in

Table 6 Incidence of sexually transmitted diseases 1985-199129

\begin{tabular}{lrrrr}
\hline Disease & 1985 & 1987 & 1989 & 1991 \\
\hline Infectious syphilis & 677 & 465 & 591 & 512 \\
Latent syphilis & 459 & 462 & 485 & 467 \\
Congenital syphilis (early) & 9 & 7 & 2 & 7 \\
Congenital syphilis (late) & 9 & 31 & 10 & 6 \\
Gonorrhoea & 2574 & 2203 & 2099 & 1312 \\
B lactamase & 79 & 169 & 312 & 142 \\
Herpes genitalis & 1193 & 827 & 690 & 818 \\
H.I.V. positives & - & - & 11 & 16 \\
Ophthalmia neonatorum & - & - & 27 & 14 \\
\hline
\end{tabular}

health care settings for skin piercing instruments; to promote safe sex behaviour in high risk groups through information, education and counselling; to create AIDS awareness in the general population through health education and counselling; to develop a management structure for the control of AIDS and STD that will provide for intersectoral support from both the public and NonGovernmental Organisations (NGO) and strengthen surveillance, laboratory and clinical capabilities to prevent, detect, and manage these diseases.

Sero-epidemiological surveys were carried out in high risk groups including STD patients, male and female prostitutes prisoners and workers connected with the tourist industry. Such surveys were carried out in high risk areas (those in contact with foreigners) such as Colombo, Hikkaduwa, Kandy, Jaffna, Negambo, Matare, Nuwara Eliya and Bentota. Since September 1986, a total of 362,123 HIV tests has been performed. Sixty-six HIV positive individuals have been identified and they included 52 Sri Lankan nationals and 14 foreigners. Of the Sri Lankans who were found to be HIV positive, 19 have developed AIDS and 18 have died. ${ }^{30}$ Indigenous transmission which was recorded first in the country in December 1989 is now established. It represents about $30 \%$ of the transmission. Transmission so far appears to be exclusively sexual, with heterosexual exposures showing marked predominance over homosexual exposures. Whilst the number of detected HIV positives so far is small, it is estimated that there are around 1500 persons infected with the virus. ${ }^{29}$ Even though the number of detected seropositive persons is small in Sri Lanka, there is no cause for complacency as the epidemic is now firmly established in other countries like India, Thailand and Myanmar. Massive increases in the number of HIV positive cases amongst sex industry workers have been reported in some areas like Chiang Rai Province in Thailand within a very short period of time. ${ }^{31}$ This causes much concern in countries like Sri Lanka where similar patterns of risk behaviours are present. Needle using drug abuse is considered to be a limited activity in Sri Lanka but addicts using drugs orally and by inhalation are prevalent mostly in areas where tourism thrives. This group has to be considered at risk as the practices could change very quickly.

We thank Dr Michael Waugh, the Senior Consultan Physician, Department of Genito-Urinary Medicine, The General Infirmary at Leeds, U.K. for guidance given during General Infirmary at Leeds, U.K. for guidance given during the formulation of this paper, Dr S M Laird (formerly WHO Consultant) for providing us with the documents related to his work in Ceylon, and Dr C S Ratnatunga, formerly consultant attached to the VD clinic in Colombo, and Dr R S Morton, formerly senior consultant in Genitourinary Medicine, Sheffield, for their help. Finally we thank the WHO Geneva office for providing us with valuable information regarding venereal diseases and HIV infection in Sri Lanka.

1 Sri Lankan Government Census 1991

2 De Silva WR, Fournal of Royal Asiatic Society (Ceylon)

$1913 ; 33$, p 35.
Pereira EDC, Br $\mathcal{F}$ Venereal Dis 1962;38:90. 
4 Pereira EDC, Ratnatunga CS, Br $\mathcal{f}$ Venereal Dis 1965; 41:97.

5 Atygalla J. Fournal of Royal Asiatic Society, (Ceylon) 1913; 33:46.

6 Paragraph 2 of report on the Parangi disease of Ceylon prepared by WR Kinsey, Ceylon sessional papers viii (1881) p 49-132.

7 Papers on yaws and some allied diseases, Gavin Milroy, Medical Times and Gazette, 4 November 1876, 17 November 1877, 23 November 1878 .

8 Castellani Aldo, Microbes, Men and Monarchs, 1960, 71, London, Victor Gollancz.

9 Castellani Aldo, On the presence of spirochaetes in two cases of ulcerated parangi (yaws) BMF, 1905;2:1280.

10 Wellman FC. On a spirochaete found in a yaws papule, f Tropical Med Hyg. 1905;8:345.

11 Ceylon Sessional Papers xv 19223 and 4

12 Spittell, RL. (1923) Framboesia Tropica (Parangi of Ceylon) London, Bailliere, Tindall and Cox, 57.

13 Ferguson's Ceylon Hand Book and Directory, 1898-1899, Colombo (publisher unknown) 608.

14 Laird, SM, 1952, WHO-INT/VDT/120, 27.

15 Morton, RS, British fournal of Sexual Medicine, 1992;19: 139.

16 Lees, $\mathrm{R}, \mathrm{Br} \mathcal{F}$ Venereal Dis 1961;37:187.

17 WHO IC/VD/8 November 1947

18 Administration Report of the Director of Medical and Sanitary Services for 1951, B.208, para 364
19 Laird, SM, Roses in December, Braunton, Devon Merlin Books. 1990; 164.

20 Laird, SM, WHO/VDT/120, 1959.

21 Report of the Kandyan Peasantry Commission. Ceylon Sessional paper 1952, page 181 para. 365

22 Copies of Professor Leiby's Report are available in the WHO Regional office (New Delhi), and WHO Headquarters, Geneva.

23 Laird, SM. Final Report by the Senior Adviser, on leaving the project, (WHO INT/VD/57 of 13 Oct. 1952.)

24 Laird, SM. Prevalence of Syphilis in Ceylon, Brf Venereal Dis 1954;30:98.

25 Ratnatung CS. Venereal Diseases in Ceylon, WHO/ VDT $/ 328.65$

26 WHO Project Ceylon 005. Dr SM Laird WHO consultant's Report SEA/VDT/11 15 July 1968.

27 Fernando, WL. Physician reporting of venereal disease in Ceylon, Br $\mathcal{f}$ Venereal Dis 1972;48:361.

28 Anonymous Annual Health Bulletin, Sri lanka, Colombo. Sri lanka Ministry of Health, Government Press 1986 102.

29 Annual Health Bulletin, Government of Sri lanka, Government Press, 1992 p.138.

30 National Aids/STD Prevention and Control Programme, Sri lanka Quarterly Progress Report July-September 1992.

31 Bamber SD, Hewison KJ, Underwood PJ, Genitourin Med 1993;69:153. 